\title{
Results from the University of Toronto continuous flow diffusion chamber at ICIS 2007: instrument intercomparison and ice onsets for different aerosol types
}

\author{
Z. A. Kanji ${ }^{1, *}$, P. J. DeMott ${ }^{2}$, O. Möhler ${ }^{3}$, and J. P. D. Abbatt ${ }^{1}$ \\ ${ }^{1}$ University of Toronto, Department of Chemistry, Toronto, ON, Canada \\ ${ }^{2}$ Colorado State University, Department of Atmospheric Science, Fort Collins, CO, USA \\ ${ }^{3}$ Karlsruhe Institute of Technology, Institute for Meteorology and Climate Research, Karlsruhe, Germany \\ *now at: Institute for Atmospheric and Climate Science, ETH, Zurich, Switzerland
}

Received: 28 August 2010 - Published in Atmos. Chem. Phys. Discuss.: 1 September 2010

Revised: 17 December 2010 - Accepted: 20 December 2010 - Published: 3 January 2011

\begin{abstract}
The University of Toronto continuous flow diffusion chamber (UT-CFDC) was used to study heterogeneous ice nucleation at the International Workshop on Comparing Ice Nucleation Measuring Systems (ICIS 2007) which also represented the 4-th ice nucleation workshop, on 14-28 September 2007. One goal of the workshop was to intercompare different ice nucleation measurement techniques using the same aerosol sample source and preparation method. The aerosol samples included four types of desert mineral dust, graphite soot particles, and live and dead bacterial cells (Snomax $\left.{ }^{\circledR}\right)$. This paper focuses on the UT-CFDC results, with a comparison to techniques of established heritage including the Colorado State CFDC and the AIDA expansion chamber. Good agreement was found between the different instruments with a few specific differences, especially at low temperatures, perhaps due to the variation in how onset of ice formation is defined between the instruments and the different inherent residence times. It was found that when efficiency of ice formation is based on the lowest onset relative humidity, Snomax ${ }^{\circledR}$ particles were most efficient followed by the desert dusts and then soot. For all aerosols, deposition mode freezing was only observed for $T<45 \mathrm{~K}$ except for the dead bacteria where freezing occurred below water saturation as warm as $263 \mathrm{~K}$.
\end{abstract}

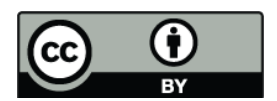

Correspondence to: Z. A. Kanji (zamin.kanji@env.ethz.ch)

\section{Introduction}

The role of ice clouds in determining the global radiation budget is not fully understood (IPCC, 2007). Part of the gap in knowledge comes from the lack of understanding or quantification of ice formation processes in the atmosphere, including those associated with heterogeneous ice formation where solid substrates called ice nuclei (IN) are involved in the ice forming process (Cantrell and Heymsfield, 2005). Difficulties arise in quantifying conditions of heterogeneous ice formation because of the varied composition and size distributions of IN found in the atmosphere. For example IN can span compositions from elemental carbon (soot), to biological aerosols (bacteria and pollen) and crustal aerosol (mineral dusts) (Andreae and Rosenfeld, 2008 and references therein). Within each classification there are further variations based on aerosol size, source or production method. For example, with desert dust manufactured to represent dusts emitted from Arizona it has been observed that the mineralogical composition varies with size of the particle (Vlasenko et al., 2005). Ice formation is dependent on the composition of IN, relative humidity, temperature and size of IN (Archuleta et al., 2005; Dymarska et al., 2006; Kanji and Abbatt, 2006, 2009a; Kanji et al., 2008; Welti et al., 2009). In addition, when investigated in the laboratory, more factors such as aerosol preparation and preconditioning as well as ice particle detection methods and observation time become potentially important factors to consider when reporting ice formation requisites. Finally, exposure to trace species (organics, $\mathrm{NH}_{3}, \mathrm{NO}_{\mathrm{x}}, \mathrm{SO}_{2}, \mathrm{O}_{3}$ ) may further modify the surface of IN (Salam et al., 2007; Kanji et al., 2008; Salam et al., 2008). 
Prompted in part by the outstanding questions/issues in the field (Laaksonen et al., 1995; Szyrmer and Zawadzki, 1997; Cantrell and Heymsfield, 2005), a suite of laboratory studies have recently emerged on the study of heterogeneous ice nucleation. These include studies isolating immersion freezing (Zobrist et al., 2006; Marcolli et al., 2007) and condensation and deposition freezing (e.g., DeMott et al., 1999; Möhler et al., 2005b; Abbatt et al., 2006; Dymarska et al., 2006; Knopf and Koop, 2006; Möhler et al., 2006; Salam et al., 2006; Eastwood et al., 2008; Stetzer et al., 2008; Eastwood et al., 2009). In addition, field studies (Chen et al., 1998; DeMott et al., 2003; Cziczo et al., 2004; Ansmann et al., 2005; Twohy and Poellot, 2005) have also played a vital role in identifying aerosols that are good IN or most frequently associated with ice crystals in the atmosphere. These studies serve to direct the type of systematic investigations of heterogeneous ice nuclei in the laboratory setting.

The general conclusions from laboratory and field investigations are that mineral dusts are more efficient ice nucleators than soot type aerosols and for studies that have included organics, oxidised organics are better at ice nucleation than reduced (alkyl type) species (Kanji et al., 2008). However, there are a number of differences between results reported that arise from the different techniques used. These could benefit from a more detailed comparison between experimental techniques to better define the representation of ice nucleation results (Vali, 1975). Given the wide variety of ice nucleation instruments used currently, differences in ice nucleation observations will in part arise from the different techniques used. To isolate these effects, it is important to eliminate variability that might arise from aerosol source, preparation and sampling methods. It may then be possible to determine which differences have meaning for ice nucleation properties versus being experimental artifacts.

Renewed interest in ice nucleation research and the development of new instruments prompted The Fourth International Ice Nucleation workshop, ICIS 2007 (DeMott et al., 2010). The goal of the workshop was to perform an intercomparison of ice nucleation measurement systems while sampling aerosols of the same size distribution and source at similar temperatures. The workshop took place at the AIDA (Aerosol Interactions and Dynamics in the Atmosphere) facility at Karlsruhe Institute of Technology (Institute for Meteorology and Climate Research) in Germany, between 1428 September 2007. The third such workshop took place in Laramie, Wyoming in 1975 Vali, 1975). Some of the major conclusions from the third workshop were that supersaturation played an important role in determining the activation of IN, further ice nucleation measurements must completely document aerosol properties and new instruments should undergo extensive testing, controls and validation by comparison to pre-existing instruments before being implemented for atmospheric sampling (Vali, 1975). In response to these suggestions, new instruments are being validated before implementation in laboratory or field studies, for example see
Stetzer et al. (2008) and Kanji and Abbatt (2009b) for recent examples. This in part responds to some of the suggestions highlighted in the conclusions of the third workshop while ICIS, 2007 takes into account the other suggestions, such as sampling at different supersaturations and temperatures for a given aerosol type and maintaining a complete database on aerosol properties.

In the current study we present the first detailed results from the new University of Toronto continuous flow diffusion chamber (Kanji and Abbatt, 2009b), and compare these results to those from the AIDA cloud chamber performing "expansion experiments" and to Colorado State University (CSU) CFDC. Details about the operation of these wellestablished ice nucleation chambers can be found in Möhler et al. (2006) and Rogers et al. (2001), respectively. Additional modifications to the CSU CFDC occurred in 2006 and are presented elsewhere (Eidhammer et al., 2010). In addition, details of the experimental schedule and configuration of all instruments in the workshop can be found in Möhler et al. (2008a) The differences between the CSU and UT instruments are primarily the orientation and geometry of the instrument and different detection criteria for ice crystals. Comparison between the expansion, CSU and UT experiments covers the majority of the techniques used at the workshop since six of ten total instruments represented were CFDCs. Note that results from the AIDA and CSU experiments along with results from other participants in the workshop are also to be presented in this special issue, and we only present a subset of these results to aid in the validation of the UT-CFDC data.

\section{Experimental}

\subsection{The UT - CFDC}

Ice nucleation was carried out in a continuous flow thermal gradient diffusion chamber whose operation has been described in detail (Kanji and Abbatt, 2009b). Briefly, the chamber, a CFDC with horizontal orientation whose inner walls are coated with ice and temperature controlled by external re-circulating chillers, is fed with aerosols through a movable stainless steel injector. The aerosol constitutes $10 \%$ of the total flow of $2.83 \mathrm{lpm}$ and the remainder is made up of dry particle-free synthetic air. The temperature of both walls is varied at similar rates such that the temperature in the centre of the chamber, where the aerosols are injected, remains constant. Upon increasing the difference in temperature between the two walls, a supersaturation with respect to ice develops in the chamber. When ice forms, the particles grow to sizes beyond those of the aerosols and are detected by an optical particle counter (Climet Instruments Model CI20). The counter can measure particles in two size bins, with diameters greater than 0.5 and $5 \mu \mathrm{m}$. However, due to the size distribution of sampled aerosols sometimes extending 
beyond $0.5 \mu \mathrm{m}$, the smaller channel often displayed a high background count and was not used in this work to determine the onset of ice formation. All experiments were RH scans where the average temperature at the centre of the chamber was kept constant and the RH was increased. The temperature range of the experiments was $265-230 \mathrm{~K}$. The total number concentration of the aerosols was recorded with a condensation particle counter (CPC, TSI - 3010) that sampled at a flow rate of $1 \mathrm{lpm}$. Given the temperature range investigated, activation of aerosols could theoretically have occurred to form either water drops or ice crystals in some experiments. For more hygroscopic aerosols, water uptake can take place at conditions that are subsaturated with respect to water. However, these particles would not grow in to the $5 \mu \mathrm{m}$ channel and are of no concern during this study.

To distinguish between the liquid and ice phases we depend on the size of the activated particles and therefore used the large channel of the optical particle counter (OPC), which detects particles $>5 \mu \mathrm{m}$, to indicate ice formation. The residence time for the particles in the chamber was between 9$11 \mathrm{~s}$, for the temperature range 265 to $230 \mathrm{~K}$, respectively. For the residence times used, and based on the differential growth rates of ice and water, we have determined that there is more than enough time for the ice particles to grow to $5 \mu \mathrm{m}$ with any water drops remaining well below $5 \mu \mathrm{m}$ in diameter for $T<250 \mathrm{~K}$ (Kanji and Abbatt, 2009b). In particular, for the residence times used at ICIS 2007, water drops would grow to $5 \mu \mathrm{m}$ at $T=250 \mathrm{~K}, \mathrm{RH}_{\mathrm{w}}>103 \%$. Therefore, for all experiments carried out at $T>250 \mathrm{~K}$, we do not have the ability to attribute activation above water saturation specifically to ice or water.

Finally, the activated fraction was calculated as the ratio of ice counts from the $5 \mu \mathrm{m}$ channel to $\mathrm{CN}$ counts. The errors in all RH's reported amount to $\pm 4 \%$ and mostly arise from the uncertainty of temperature $( \pm 0.1 \mathrm{~K})$ measurements along the walls of the chamber.

\subsection{Experimental overview of AIDA expansion and CSU experiments at ICIS-2007}

The AIDA cloud expansion experiments operate on the principle of adiabatic expansions that result in rapid cooling and thus increasing RH inside a $84 \mathrm{~m}^{3}$ cylindrical chamber (Möhler et al., 2006). To simulate pseudo-adiabatic cooling of rising air parcels, the pressure within the chamber is reduced with a mechanical pump from 1000 to $800 \mathrm{hPa}$ which resulted in typical mean cooling rates of $1-2 \mathrm{~K} \mathrm{~min}^{-1}$. Aerosol concentrations were measured using a CPC (TSI, 3010) that was modified to sample at low pressures. Ice onset was reported when an increase in ice crystal numbers were observed using a Welas OPC well described in Benz et al. (2005). In addition the Welas OPC can detect particles as small as $0.8 \mu \mathrm{m}$ and the ice threshold size is chosen to be sufficiently large so that the largest aerosol particles and any liquid drops present are omitted from being counted as ice since ice crystals grow to substantially larger sizes (Wagner et al., 2006). An in situ multi-reflection path tunable diode laser absorption spectrometer directly measures the water vapour concentration in the chamber volume. Uncertainty estimates in computed $\mathrm{RH}$, arising mostly from the water vapour and temperature measurements, are $\pm 4-6 \%$ (Field et al., 2006; Möhler et al., 2006).

The CSU chamber operates on the same basic principle as the UT-CFDC, however there are a few differences between the two instruments, including the orientation, the detection limit for what constitutes an ice crystal, and the presence of a region in the lower portion of the CSU-CFDC where droplet evaporation is induced. The CSU chamber has a circular geometry with two vertically oriented concentric cylinders, whereas the UT chamber is horizontal. Sample and sheath flows are injected into the annular gap between the outer and inner cylinders, where the inner walls of the chamber are coated with ice and held at different temperatures. The lower third of the chamber is actively controlled with both iced walls at the same (cold wall) temperature so that water droplets evaporate to sizes below the ice detection size before passing into the detector as long as the set point $\mathrm{RH}_{\mathrm{i}}<108 \%$ (DeMott et al., 2008; Eidhammer et al., 2010). At the inlet of the chamber an inertial impactor removes particles larger than $1.2 \mu \mathrm{m}$. The detector was an optical particle counter (Climet, CI - 3100) that detected particles larger than $2 \mu \mathrm{m}$ as ice crystals. The $\mathrm{CN}$ counts from the CPCs used for the expansion experiments were also used to provide $\mathrm{CN}$ counts for the CSU chamber. Residence times were $4-5$ seconds in the chamber growth region, about half those in the UTCFDC. The RH uncertainty is $\pm 3 \%$. For more details of the CSU chamber at ICIS-2007 see Koehler et al. (2010)

\subsection{Aerosol preparation and sampling}

All aerosol samples were originally contained in an aerosol preparation and characterization (APC) chamber, a $3.7 \mathrm{~m}^{3}$ evacuable vessel that is made of stainless steel and operated at room temperature. Except for the bacteria and soot, the aerosols were dry dispersed into the chamber using a rotating brush disperser (RBG 1000, Palas) in dry synthetic air (Möhler et al., 2006). For both the bacteria samples, aqueous suspensions were made in de-ionised distilled water $\left(5 \times 10^{9}\right.$ Cit7 cells $/ \mathrm{ml}$ ) and dispersed into the chamber using a dispersion nozzle. The aerosol samples used were:

1. Arizona Test Dust (ATD) (Powder Technology Inc., Minnesota, USA).

2. Saharan Dust (SD) a surface sample collected $50 \mathrm{~km}$ north of Cairo City Egypt.

3. Canary Island Dust (CID) a surface sample collected near the town of Mala on the Canary Island of Lanzarote. 
4. Israeli Dust (ID) collected from Ramat Hashron, Israel, following a dust storm.

5. Graphite spark generated soot (GSG).

6. Live bacteria (LB) and Snomax® (dead bacteria) (Möhler et al., 2008b).

The soot particles were produced by a commercial graphite spark generator (GfG 1000, Palas) at maximum spark capacity between two pure graphite electrodes and with $99.999 \%$ purity Ar flowing at $5.01 \mathrm{pm}$. Soot particles used were a surrogate for low organic carbon content $(\sim 10 \%)$ aerosol and contained mostly elemental carbon. More details on the soot aerosol can be found elsewhere (Möhler et al., 2005a). The bacteria come from cultures of Pseudomonas Syringae, in particular the Cit7 strain. The bacteria were grown in a microbiology laboratory, washed in a centrifuge before making an aqueous suspension. Snomax ${ }^{\circledR}$ is the same species but commercially processed, freeze dried and killed by gamma radiation. It is used in artificial snow making.

Size distributions were measured (SMPS, APS 3021) and are described in Table 1 for particles in the APC chamber. The upper sizes are based on assuming spherical equivalent particles of density $2.6 \mathrm{~g} \mathrm{~cm}^{-3}$ for dust and $1.4 \mathrm{~g} \mathrm{~cm}^{-3}$ to process the APS data. Note that size distributions in the AIDA chamber were not identical to the APC chamber for every experiment even though particles in AIDA came from the APC chamber. For the bacteria samples, the bi-modal distribution arises from soluble material associated with the matrix of the bacterial solution and bacterial cells. Transmission electron microscopy confirms that the bacteria were present in the size range $0.4-2.0 \mu \mathrm{m}$ with the bacterial cells being on the order of $0.7 \mu \mathrm{m}$.

The aerosols were typically sampled from the APC chamber at ambient pressure, however there were also opportunities during the workshop to sample from the AIDA cloud expansion chamber directly, in which case the aerosols were at lower temperatures than the APC chamber and at much lower concentrations. Since the aerosol lines from the AIDA chamber to the respective instruments were at room temperature (except for the CSU-CFDC), the aerosols warmed up to room temperature prior to entry to the UT system. There was also a chance to sample aerosols from the AIDA chamber after a cloud expansion (i.e. ice activation) experiment. This allowed for the investigation of ice formation onto the particles that did not grow to large sizes or activate at all during an expansion and therefore were not removed due to gravitational settling. Fig. 1 shows the relative positions of the CSU and UT-CFDC chambers.

\section{Results and discussion}

In Fig. 2, we plot all the ICIS results from UT-CDFC. We then compare our results to those from the different
Table 1. Size distributions of aerosol samples in APC chamber.

\begin{tabular}{lrr}
\hline Aerosol Type & $\begin{array}{r}\text { Approx. Size } \\
\text { Range }(\mu \mathrm{m})\end{array}$ & $\begin{array}{r}\text { Number } \\
\text { Mode }(\mu \mathrm{m})\end{array}$ \\
\hline $\begin{array}{l}\text { Arizona Test Dust } \\
\text { (ATD) }\end{array}$ & $0.02-2.00$ & 0.20 \\
$\begin{array}{l}\text { Graphite Spark } \\
\text { Generator Soot } \\
\text { (GSG) }\end{array}$ & $0.02-0.45$ & 0.15 \\
$\begin{array}{l}\text { Israeli Dust } \\
\text { (ID) }\end{array}$ & $0.03-3.00$ & 0.30 \\
$\begin{array}{l}\text { Saharan Dust } \\
\text { (SD) }\end{array}$ & $0.03-2.00$ & 0.30 \\
$\begin{array}{l}\text { Canary Island Dust } \\
\text { (CID) }\end{array}$ & $0.02-1.50$ & 0.20 \\
$\begin{array}{l}\text { Snomax® } \\
\text { (CID) }\end{array}$ & $0.04-1.5$ & 0.10 \\
$\begin{array}{l}\text { Live Bacteria } \\
\text { (LB) }\end{array}$ & $0.04-2.00$ & 0.10 and 0.70 \\
\hline
\end{tabular}

instruments while sampling from either the APC or AIDA chamber (Figs. 3-7). For the bacteria samples we do not present an inter-comparison because of the small number of experiments performed and because most were are at $T \sim 263 \mathrm{~K}$ and $\mathrm{RH}_{\mathrm{w}} \sim 100 \%$ where we believe UT-CFDC cannot distinguish between ice particles and water droplets. For all figures, the metric for comparison of results are the RH's for $0.1 \%$ of particles activating ice.

\subsection{General comparison of ice nuclei (IN) sampled}

To infer modes of ice formation we assume that activation below water saturation proceeded by deposition nucleation, acknowledging that the specific influence of adsorption or condensation processes cannot be discerned there, and activation at or above water saturation proceeded by condensation/immersion freezing to given that we do not know if nuclei freezing during condensation of water drops at low temperatures are distinct from ice nuclei that would freeze following immersion at warmer temperatures. We refer to freezing above water saturation as condensation instead of immersion since we did not actively cool immersed particles in the experiments discussed. In Fig. 2, for the higher temperatures the dust aerosols are only active at or above water saturation indicating that deposition mode freezing is probably not the preferred pathway of ice formation. ATD begins to show some ice activation below water saturation at $T<245 \mathrm{~K}$ while SD and CID only become active in the deposition regime at $T<240 \mathrm{~K}$. When the temperature is approximately $230 \mathrm{~K}$ both ATD and CID begin activating ice crystals well below water saturation. There is some difference in observed ice onset RH's when comparing particles sampled from the APC and AIDA chambers. For ATD, the 


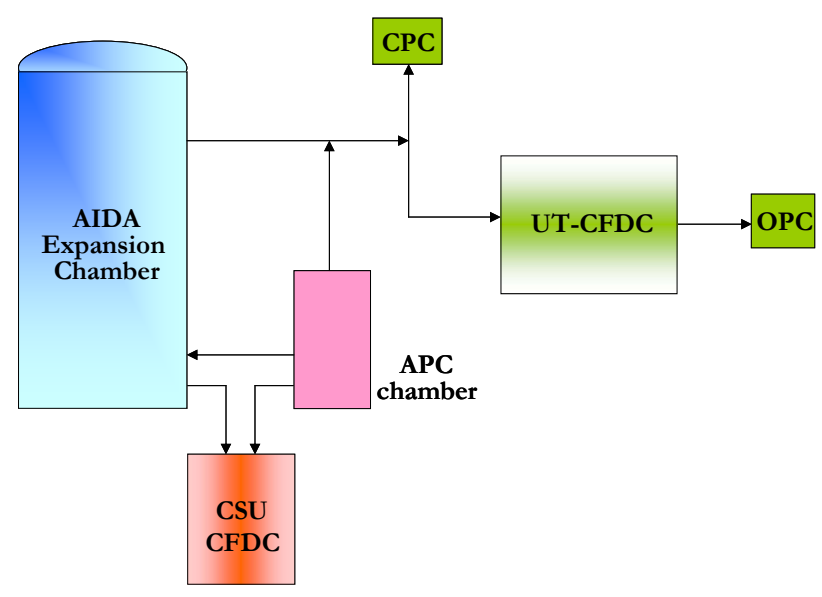

Fig. 1. Schematic of instruments arranged relative to sampling chambers at ICIS 2007 at the AIDA facility at Karlsruhe, Germany. The height of the chamber spanned approximately 4 floors. The UT-CFDC was one floor above the CSU-CFDC which was on the ground floor. Arrows indicate the direction of aerosol flow. For details of analytic instruments coupled to the AIDA chamber see Möhler et al. (2006) and Möhler et al. (2008).

AIDA (pre-expansion) onset is higher than those for APC particles (see Fig. 2). This could be due instrumental variability since the data points fall within their levels of uncertainty $( \pm 4 \%)$. In addition, the higher onset from particles sampled from AIDA could also pertain to the size of the aerosol sampled. Since the UT-CFDC sampling line from the AIDA chamber was much longer than the line from the APC chamber, it is possible that large particles were lost while sampling from AIDA. As reported in Archuleta et al. (2005); Kanji and Abbatt (2009a) and Welti et al. (2009) larger particles lead to lower onset RHs of ice formation. Lower onsets would then be expected while sampling from APC.

The bacteria samples and Snomax ${ }^{\circledR}$ mostly activated at the $0.1 \%$ level around water saturation at $T>260 \mathrm{~K}$. Due to the uncertainty in RH measurement it is not possible to state if freezing proceeds by condensation or deposition mode. However, Snomax ${ }^{\circledR}$ activates ice well below water saturation, implying deposition freezing at $T=247 \mathrm{~K}$ forming ice at $\mathrm{RH}_{\mathrm{i}}$ that is $10 \%$ lower than that required for SD, ID and CID at the same temperature. This is more active than all of the dust particles sampled. Snomax ${ }^{\circledR}$ is clearly the most efficient IN of all the samples. Note that the data points at $T \sim 263 \mathrm{~K}$ are close enough to water saturation that the UT-CFDC instrument could be measuring water activation and/or condensation freezing.

At the lower temperatures GSG is also found to be active in the deposition mode. However, it is a less efficient IN than ATD or CID. Activation below water saturation for GSG is apparent at $T<235 \mathrm{~K}$. At warmer temperatures soot only activates as ice crystals via condensation freezing at or above water saturation. Warm temperature data points have been

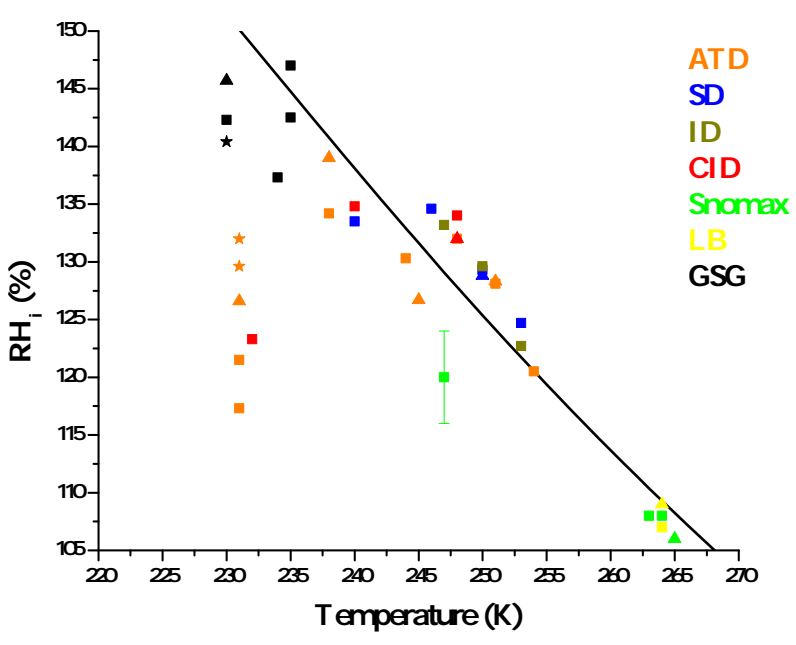

Fig. 2. Onset $\mathrm{RH}_{\mathrm{i}}$ for $0.1 \%$ activated ice fraction as a function of temperature for all aerosols sampled with the UT-CFDC. All data are based on the large particle channel $(>5 \mu \mathrm{m})$. UT-CFDC data at $\mathrm{RH}_{\mathrm{W}}>100 \%$ and $T>250 \mathrm{~K}$ could represent ice and/or water activation. Triangles: aerosol sampled from AIDA chamber. Squares: aerosol sampled from APC chamber. Stars: aerosol sampled after a cloud expansion experiment in AIDA. Black line: Water saturation (Murphy and Koop, 2005). Uncertainty in all data points $\pm 4 \%$.

omitted from the comparison since not enough growth was observed in the $5 \mu \mathrm{m}$ OPC channel to deduce $0.1 \%$ ice activated fractions, implying that GSG is a poor ice nucleus at $T>235$.

\subsection{Arizona test dust}

In Fig. 3 we plot results from experiments carried out with ATD from $256-223 \mathrm{~K}$. Also shown are particle results from the CSU chamber, the cloud expansion experiments and sizeselected measurements made in our laboratory at University of Toronto (Kanji and Abbatt, 2009a). It is apparent that for most of the warmer temperature experiments ice formation is only observed at water saturation or above, implying condensation freezing of ATD. Deposition mode freezing becomes apparent at about $240 \mathrm{~K}$. Below this temperature the ice onset is well below water saturation. For the warmer temperature work there is in general good agreement between the UT-CFDC, CSU-CFDC and expansion experiments. Note that some AIDA data are plotted at $100 \% \mathrm{RH}$ because this is the approximate condition of ice formation during continued cooling following initial cloud formation. All particles are immersed by acting as $\mathrm{CCN}$ at undefined $\mathrm{RH}_{\mathrm{w}}>100 \%$ during these cloud expansions after which the relative humidity in the cloud is $100 \%$ due to activation of all particles despite subsequent freezing. To achieve comparative simulations with the CFDCs operating at the same observation temperatures, it is necessary to achieve water supersaturations, the calculated values of which are reported. Thus, although we assume that the ice nucleation mechanisms are similar, it is 
not clear if any significance can be ascribed to the difference between CFDC and AIDA RH in these cases. It would be necessary to operate AIDA for repeated expansions at the exact cloud onset temperatures where the CFDCs operated.

For the UT-CFDC experiments it is generally observed that the onsets of ice formation when sampling from APC are lower than when sampling from AIDA, as addressed in the previous section. For the CSU-CFDC experiments this difference between APC and AIDA is not observed. It is possible that because the CSU instrument used an inlet impactor while sampling, which was not used for the UT-CFDC, that the latter sampled larger particles from the APC chamber than CSU. Simple calculations of the proportion of all particles not sampled by the CSU instrument due to the preimpactor $50 \%$ size cut average gave values of $0.05 \%$ (1.5 particles $\mathrm{cm}^{-3}$ ) for ATD size distributions from the APC chamber. As support for this idea, we also plot in Fig. 3 data collected at The University of Toronto using the UT instrument from an aqueous suspension of ATD (Kanji and Abbatt, 2009a). For $100 \mathrm{~nm}$ particles deposition freezing is only apparent below $233 \mathrm{~K}$. At $223 \mathrm{~K}$, larger ATD particles are much more efficient at forming ice. Therefore, if sampling a polydisperse sample, as was done in ICIS 2007, it is likely that lower onset RHs will be observed in the presence of larger particles.

The data points between $233-231 \mathrm{~K}$ in Fig. 3 shows a significant spread in RH given that they are all collected at similar temperatures. For the UT data points when sampling directly from AIDA, there is a systematic increase in onset RH for each successive expansion experiment. Here, we believe that the loss of larger ice crystals, hence larger particles to gravitational settling upon ice formation, leaves behind smaller, less efficient particles (Kanji and Abbatt, 2009a; Welti et al., 2009) for the 2nd and 3rd activations, thus requiring higher RH to initiate ice formation. This is the reason for the systematic increase in onset from experiment to experiment. Note that in Fig. 3 the "pre-exp" and "post-2nd exp" data points are far apart enough that our uncertainties in measurement cannot be used to explain the differences. This is also true for the difference between UT(APC) at $T \sim 231 \mathrm{~K}$ and "post-1st exp" data points.

In some cases when sampling from APC, the CSU-CFDC observes lower onsets than the UT-CFDC and this could be attributed to the detection abilities of the instruments. The OPC used with the CSU detects ice particles that are larger than $2 \mu \mathrm{m}$ while UT detects ice particles that are larger than $5 \mu \mathrm{m}$, thus requiring slightly higher RHs $(T=233 \mathrm{~K}$, $\mathrm{RH}_{\mathrm{w}} \geq 76 \%$ ) for particles to grow to a larger size. This effect would be more pronounced if activations occurred at low RHs or at very cold temperatures where ice growth rates were lowest.

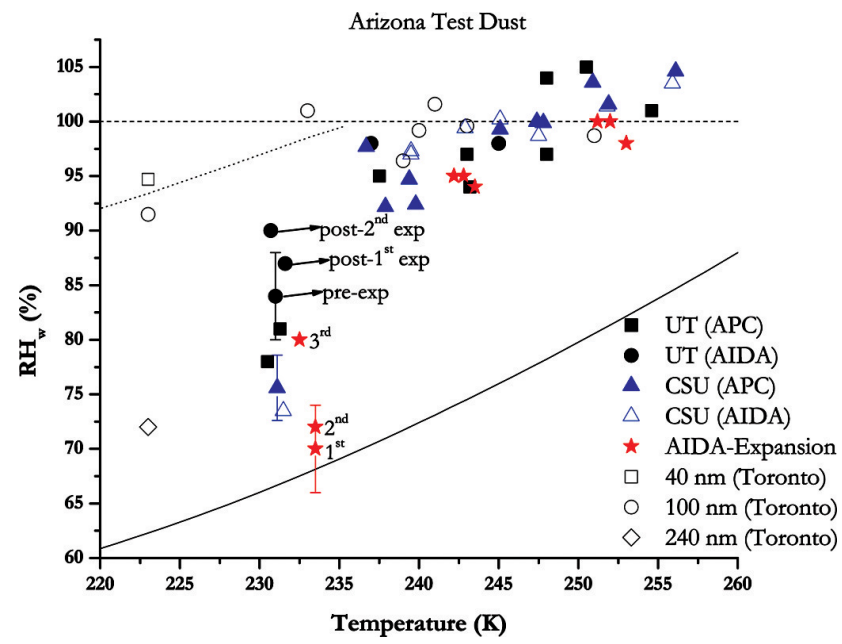

Fig. 3. Comparison of onset $\mathrm{RH}_{\mathrm{w}}$ for $0.1 \%$ activated ice fraction as a function of temperature for Arizona Test Dust aerosols between UT, CSU and AIDA experiments. UT-CFDC data based on $5 \mu \mathrm{m}$ channel except for the size selected studies where backgrounds were low enough to use the $0.5 \mu \mathrm{m}$ channel. UT-CFDC data at $\mathrm{RH}_{\mathrm{W}}>100 \%$ and $T>250 \mathrm{~K}$ could represent ice and/or water activation. Numbers next to the stars indicate the order of the cloud expansion experiment. Pre-exp and post-exp indicate sampling from the AIDA chamber before and after successive cloud expansion experiments. Error bars represent uncertainty in RH measurements. Dashed and solid lines: Water and ice saturation, respectively (Murphy and Koop, 2005). Dotted line: Homogeneous freezing conditions for $0.1 \% 300 \mathrm{~nm}$ ammonium sulphate aerosols in 10 s (Koop et al., 2000; DeMott et al., 2009).

\subsection{Saharan, Canary Island and Israeli dusts}

To assess the relative efficiencies of different dusts, three other mineral dust samples were studied. In Fig. 4 we plot the data for ice formation onto SD aerosol. Deposition mode freezing is likely occurring at $T<246 \mathrm{~K}$ above which freezing is only observed at or above water saturation for AIDA, UT and CSU instruments. As with ATD, there is a decrease in onset RH as temperature decreases, indicating a change in freezing mechanisms from condensation to deposition freezing. For the UT data points above water saturation, it is not clear whether ice or water activation occurs because they are at the limit for when water droplets can grow large enough to be detected in the $5 \mu \mathrm{m}$ channel. For the data points observed below water saturation we can speculate the onset of deposition freezing however the RH is still close enough to water saturation such that it is within experimental uncertainty. In fact, deposition mode freezing onto polydisperse SD particulates that were deposited on a hydrophobic support at $T=233 \mathrm{~K}$ have been reported well below water saturation at $\mathrm{RH}_{\mathrm{w}}=73 \%$ (Kanji and Abbatt, 2006). Koehler et al. (2010) also report on deposition nucleation by SD particles at lower temperatures in this special issue. 


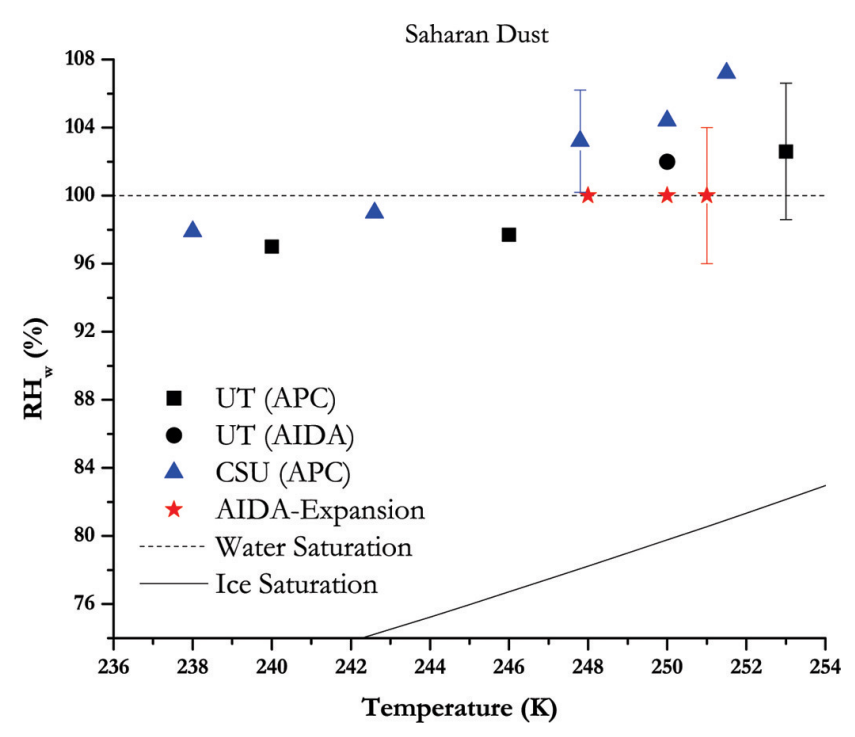

Fig. 4. Comparison of onset $\mathrm{RH}_{\mathrm{W}}$ for $0.1 \%$ activated ice fraction as a function of temperature for Saharan Dust aerosols between UT, CSU and AIDA experiments. UT-CFDC data based on $5 \mu \mathrm{m}$ channel. UT-CFDC data at $\mathrm{RH}_{\mathrm{W}}>100 \%$ and $T>250 \mathrm{~K}$ could represent ice and/or water activation. Error bars represent uncertainty in RH measurements (see text for details). Dashed and solid lines: water and ice saturation respectively (Murphy and Koop, 2005).

In Figs. 5 and 6 data are plotted for ice formation onsets as a function of temperature for Canary Island and Israel Dusts, respectively. The behaviour of these two dusts is qualitatively similar to that exhibited for SD. In particular, there is a distinct shift in ice formation from above to below water saturation for SD and CID. This transition temperature is roughly 248 and $241 \mathrm{~K}$ respectively, although the limited data make it difficult to resolve a clear difference in the transition temperature between the two dusts. In the case of ID, the temperature range examined by UT-CFDC was not large enough to identify this transition. However, in the range presented, the data are consistent with the water saturation requirement for onset ice formation - similar to others. For the lowest temperature runs of CID ( $T=232 \mathrm{~K}) \mathrm{UT}$ observes a higher $(7 \%)$ onset RH than CSU. This could be attributed to the delay that results in detection of $5 \mu \mathrm{m}$ for UT ice crystals compared to $2 \mu \mathrm{m}$ for CSU. For warmer temperatures this "delay of onset" is not observed and is consistent with faster ice crystal growth rates.

\subsection{Graphite spark generator soot}

In Fig. 7 we plot the onset RH for $0.1 \%$ of GSG particles freezing as a function of temperature. Ice formation was not detected in the UT-CFDC at warmer temperatures, $T>235 \mathrm{~K}$, for $\mathrm{RH}_{\mathrm{W}}<110 \%$, whereas ice formation was detected at the $0.1 \%$ threshold for a few degrees warmer in AIDA and the CSU-CFDC. For UT data the activation of deposition mode freezing appears to be below $235 \mathrm{~K}$. This

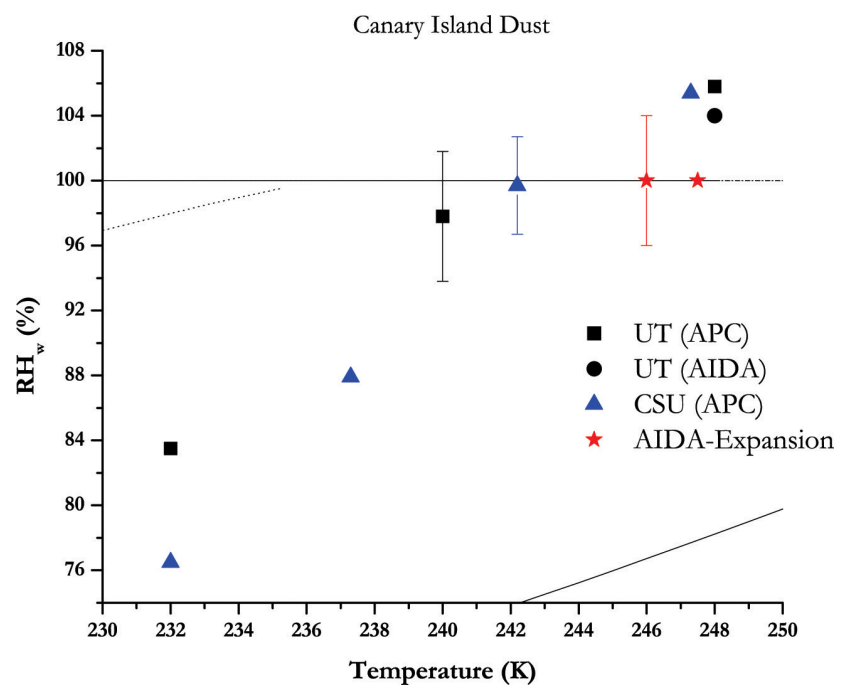

Fig. 5. Same as Fig. 4 but for CID. Dotted line: homogeneous freezing conditions for $0.1 \% 300 \mathrm{~nm}$ ammonium sulphate aerosols in $10 \mathrm{~s}$ (DeMott et al., 2009).

occurs close to but slightly below the conditions for homogeneous freezing of soluble particles of the same sizes (see homogeneous freezing line in Fig. 7). Since it is not expected that these carbonaceous particles possess soluble mass content to take up dissolved water, we believe that ice activation below water saturation represents heterogeneous nucleation in this case. The GSG sampled from the AIDA chamber resulted in the onset $\mathrm{RH}$ for the pre-expansion samples being higher than post-expansion samples. However, the data points are within measurement uncertainties and therefore no significance can be attributed to the difference in onset of ice formation. From the expansion experiments, at $T<234 \mathrm{~K}$ soot is observed to be an efficient IN as inferred by its requiring lower onset RHs, much below water saturation with decreasing temperature. At $T \sim 234 \mathrm{~K}$, the lowest $\mathrm{RH}$ is observed in the expansion experiments (deposition freezing) while CSU required water saturation, with UT coming in just below water saturation. There is a several percent RH discrepancy that is not readily explained by measurement uncertainties when comparing expansion to CSU or UT data at about 234 and $230 \mathrm{~K}$, respectively. Quantitatively, the most variation between all the results obtained from the three instruments being compared is observed for GSG. This is especially true concerning the different results from the CFDC instruments and AIDA at below about $234 \mathrm{~K}$. Figure 7 also shows data from Möhler et al. (2005) . for the same type of soot (GSG) as studied at ICIS 2007 and obtained using the same expansion chamber. These data are in agreement with the current work at warmer temperatures, however below $235 \mathrm{~K}$ the Möhler et al. (2005) study observes ice formation well below water saturation. Below $235 \mathrm{~K}$ the AIDA results measured up to several percent lower RH onsets on average than we measured with CFDC instruments. This topic 


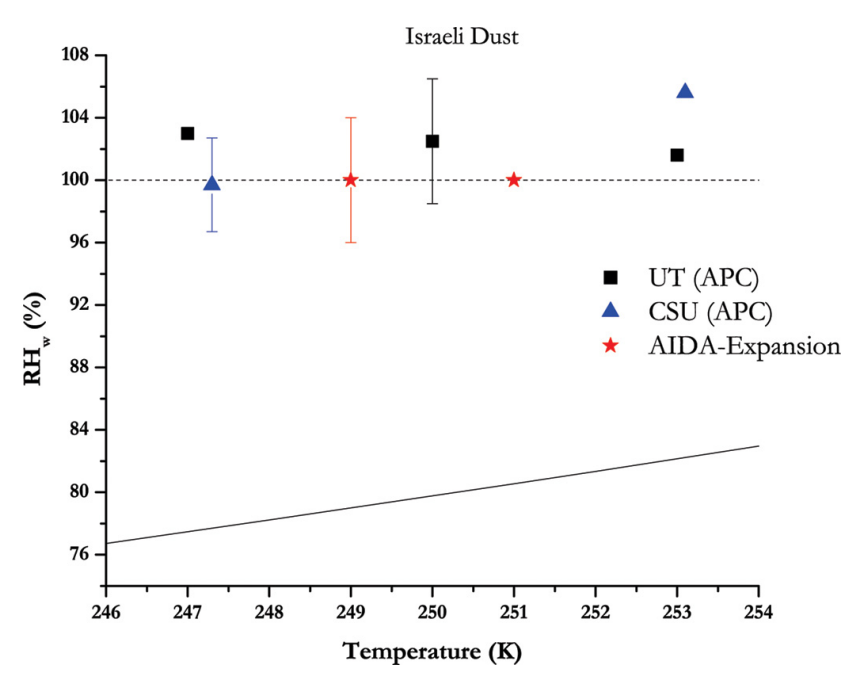

Fig. 6. Same as Fig. 4 but for Israeli Dust.

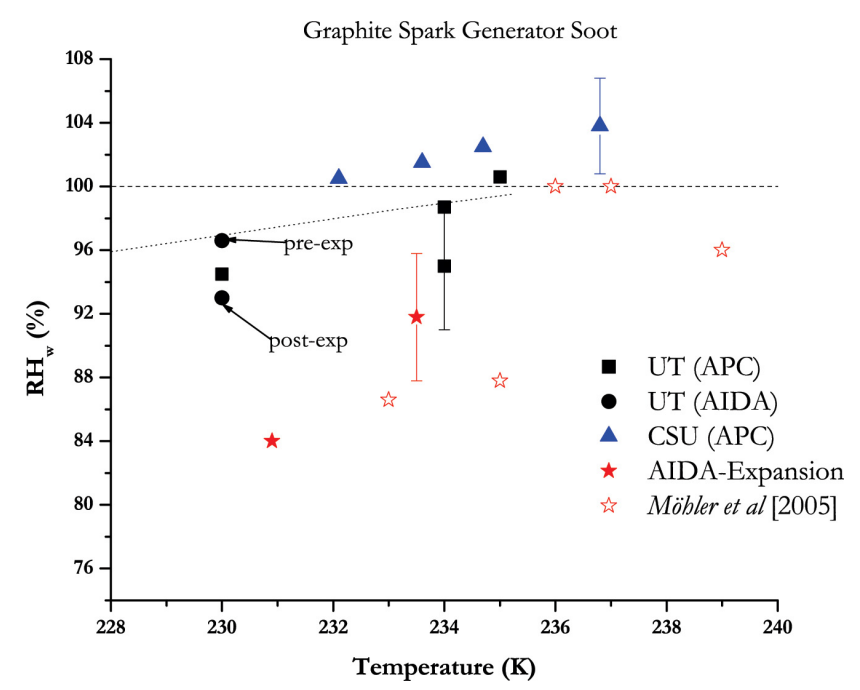

Fig. 7. Same as Fig. 5 but for graphite spark generator soot. Icesaturation line not applicable for presented scale. Pre-exp and postexp indicate sampling from the AIDA chamber before and after a cloud expansion experiment, respectively.

deserves further investigation in future studies. Some of the data in Fig. 7 suggest a transition from condensation to deposition freezing for GSG at about $234 \mathrm{~K}$ which is lower than the transition temperature for dusts (e.g. ATD at $T=245 \mathrm{~K}$ ). However, the spread in the data between the three different techniques makes it difficult to definitely state the mechanism of ice formation in these experiments. Finally, there seems to be a requirement for water saturation to form ice on GSG in the mixed phase regime.

\section{Inter-comparison of UT-CFDC, CSU-CFDC and AIDA expansion techniques}

The results indicate that for all aerosol types sampled at ICIS 2007, the UT chamber was in good agreement with AIDA expansion results, with the exception of some differences being observed at low temperatures $(T<234 \mathrm{~K}$ for ATD and GSG) where UT-CFDC gave higher onset RHs of ice formation for $0.1 \%$ of particles freezing than did the AIDA expansion chamber. This could partly be an issue of differences in the "residence time" of particles in each of the chambers. For the CFDC techniques, particles pass through the chamber within seconds whereas in the expansion chamber, particles remain in the chamber throughout the experimental run that can last for a few minutes, albeit with continued cooling. Furthermore, the $0.1 \%$ ice-active fraction point is in a regime with continuous increase of RH. Thus both CFDC and AIDA results at this threshold may be affected by the rate of change of $\mathrm{RH}$, if time dependence is an issue here. The rate of $\mathrm{RH}$ and $T$ change may be more important than the overall duration of the expansion experiment. For example, for the soot experiments, once the supersaturation had reached its maximum value in the expansion, the RH typically started to decrease thereafter. However, the ice fraction still continued to increase.

In comparing our UT-CFDC data to the CSU-CFDC results, there was generally good agreement in the $0.1 \%$ freezing metric with a few small differences to be addressed. For the UT chamber no inlet impactor was used and therefore some large particles could have been present in the samples that were absent in the CSU experiments. If this indeed was the case, it would offer an explanation for lower onset RHs observed with UT compared to CSU in some cases (see Figs. 4 and 7). However, there are examples when CSU measures lower onsets than UT, in which case this could be due to the ice crystal size detection criteria being higher for UT ( $5 \mu \mathrm{m}$ compared to $2 \mu \mathrm{m}$ for CSU). This would require higher RHs especially at colder temperatures and associated slower ice crystal growth rates for ice formation to be detected. Given the different approach used to measure ice formation in the expansion and UT-CFDC techniques, good consistency is observed when comparing results from preexpansion to post-expansion experiments. When instrument uncertainties are taken into account, good overlap is found for the onset RHs between the techniques.

\section{Conclusions}

Ice nucleation results for four types of naturally occurring mineral dust samples, graphite spark generated soot and bacterial aerosols (P. Syringae) in a horizontally oriented parallel plate CFDC have been presented as a function of temperature. Ice onsets were defined at $0.1 \%$ of aerosols activating as ice particles. It was found that dusts are more effective 
at forming ice than soot in the range $253 \mathrm{~K}>T>230 \mathrm{~K}$. At warmer temperatures, circa $247 \mathrm{~K}$, bacterial aerosols are found to form ice well below water saturation, thus being more efficient than the mineral samples studied. The onset of deposition freezing, where ice formation was observed below water saturation, takes place at $T \sim 242 \mathrm{~K}$ for the mineral dust samples. At higher temperatures, water saturation is required. Also presented are comparisons for the mineral dust and soot samples to two other instruments, the expansion chamber and a vertically oriented cylindrical CFDC. Generally good agreement between the new UT-CFDC and the older more established techniques was achieved when uncertainties for each of the techniques are taken into account, except for soot particles sampled at lower temperature. For prediction of the onset for deposition mode freezing, the three experimental methods agree on the approximate temperature range where this occurs. Significant differences in absolute values were observed in the case of GSG soot particles (Fig. 7).

The maximum spread observed between ice onset RH from the different methods was at $\sim 233 \mathrm{~K}$ (10\% for ATD and $16 \%$ for GSG). Therefore, this study also highlights factors such as residence time and ice crystal size thresholds used for detection, especially at low temperatures where kinetics may play an important role, will influence the reported onset RHs observed for ice formation. In particular, the goals from such intercomparisons and instrument development are to bring the level of agreement between conpared measurements down to the order of systematic uncertainties associated with each instrument, i.e. so the level of agreement is less than $\sim 8 \% \mathrm{RH}$ (uncertainty of 3-4\% RH for each instrument). At this point we can be more confident that issues like residence time and slightly different ice thresholds are not significantly affecting the instruments.

This comparison has highlighted the advances made in ice nucleation studies. These include being able to conduct experiments for at least two supersaturations and validating instruments before field and/or laboratory implementation. However, absolute statements about definitive onset values are still challenging to make, since experimental techniques operate in different modes. Clearly information on the full activation spectrum is also desirable. This work also suggests that rate of change of temperature and/or RH (residence time) may play a role in ice activation measurements and could benefit from future research.

Using a range of aerosol sizes also introduced further heterogeneity in samples studied during ICIS 2007. This is because larger aerosol particles will activate as ice crystals at lower RHs than smaller ones. Future ice nucleation workshops and studies may benefit from using size selected aerosols of pure substances such as oxides (e.g. silica and alumina) or pure clays (e.g. montmorillonite and kaolinite) that form a large proportion of mineral aerosol.
Acknowledgements. The authors would like to acknowledge The University of Toronto Centre of Global Climate Change Science (CGCS) scholarship and the Natural Sciences and Engineering Research Council (NSERC) for funding. The authors are thankful for the skillful support from the AIDA team for organization issues and instrument set up. We also thank Thomas Schwartz (Institut für Technische Chemie of Forschungszentrum, Karlsruhe) and Dimitrios G. Georgakopoulos (Agricultural University of Athens) for support in preparing the bacterial cultures, Eli Ganor (Tel Aviv University) for providing the Israeli dust sample, and Hans Moosmüller (Desert Research Institute) for providing the Canary Island dust sample. Forschungszentrum Karlsruhe provided funding for the facility infrastructure within the Helmholtz Research Programme "Atmosphere and Climate". The US National Science Foundation (Grant ATM-0611936) supported P. DeMott's group for this project. The European Science Foundation's INTROP program supported the data workshop in Pontresina, Switzerland.

Edited by: D. J. Cziczo

\section{References}

Abbatt, J. P. D., Benz, S., Cziczo, D. J., Kanji, Z., Lohmann, U., and Mohler, O.: Solid ammonium sulfate aerosols as ice nuclei: A pathway for cirrus cloud formation, Science, 313(5794), 17701773, 2006.

Andreae, M. O. and Rosenfeld, D.: Aerosol-cloud-precipitation interactions, Part 1. The nature and sources of cloud-active aerosols, Earth-Sci. Rev. 89(1-2), 13-41, 2008.

Ansmann, A., Mattis, I., Muller, D., Wandinger, U., Radlach, M., Althausen, D., and Damoah, R.: Ice formation in Saharan dust over central Europe observed with temperature/humidity//aerosol Raman lidar, J. Geophys. Res.-Atmos., 110(D18), doi:10.1029/2004JD005000, 2005.

Archuleta, C. M., DeMott, P. J., and Kreidenweis, S. M.: Ice nucleation by surrogates for atmospheric mineral dust and mineral dust/sulfate particles at cirrus temperatures, Atmos. Chem. Phys., 5, 2617-2634, doi:10.5194/acp-5-2617-2005, 2005.

Benz, S., Megahed, K., Möhler, O., Saathoff, H., Wagner, R., and Schurath, U.: T-dependent rate measurements of homogeneous ice nucleation in cloud droplets using a large atmospheric simulation chamber, J. Photoch. Photobio. A, 176, 208-217, 2005.

Cantrell, W. and Heymsfield, A.: Production of ice in tropospheric clouds - A review, B. Am. Meteorol. Soc. 86(6), 795-807, 2005.

Chen, Y. L., Kreidenweis, S. M., McInnes, L. M., Rogers, D. C., and DeMott, P. J.: Single particle analyses of ice nucleating aerosols in the upper troposphere and lower stratosphere, Geophys. Res. Lett., 25(9), 1391-1394, 1998.

Cziczo, D. J., Murphy, D. M., Hudson, P. K., and Thomson, D. S.: Single particle measurements of the chemical composition of cirrus ice residue during CRYSTAL-FACE, J. Geophys. Res.Atmos., 109(D4), doi:10.1029/2003JD004032, 2004.

DeMott, P. J., Chen, Y., Kreidenweis, S. M., Rogers, D. C., and Sherman, D. E.: Ice formation by black carbon particles, Geophys. Res. Lett., 26(16), 2429-2432, 1999.

DeMott, P. J., Cziczo, D. J., Prenni, A. J., Murphy, D. M., Kreidenweis, S. M., Thomson, D. S., Borys, R., and Rogers, D. C.: Measurements of the concentration and composition of nuclei 
for cirrus formation, P. Natl. Acad. Sci. USA, 100(25), 1465514660, 2003.

DeMott, P. J., Möhler, O., Stetzer, O., Murakami,M., Bundke, U., Kanji, Z., Cotton, R., Jones, H., Leisner, T., Klein, H., Cziczo, D., Petters, M., Prenni, A., Abbatt, J., Saito, A., Ardon, K., Levin, Z., Bingemer, H., Sierau, B., Nicolet, M., Bowels, J., Gallavardin, S., Targino,A., Dorsey, J., Georgakopolous, D., Rzesanke, D., Brinkmann, M., Schwartz, T., Benz, S., Wagner, R., Saathoff, H., Ebert, V., O. A. team, and Vali, G.: The Fourth International Ice Nucleation Workshop (ICIS-2007): Objectives and Preliminary Results Proceedings of 15th ICCP, Cancun, Mexico, 7-11 July 2008.

DeMott, P. J., Petters, M. D., Prenni, A. J., Carrico, C. M., Kreidenweis, S. M., Collett, J. L., and Moosmuller, H.: Ice nucleation behavior of biomass combustion particles at cirrus temperatures, J. Geophys. Res.-Atmos., 114(D16205), doi:10.1029/2009JD012036, 2009.

DeMott, P. J., Möhler, O., Stetzer, O., Murakami, M., Leisner, T., Bundke, U., Klein, H., Kanji, Z. A., Cotton, R., Jones, H., Petters, M., Benz, S., Brinkmann, M., Rzesanke, D., Saathoff, H., Nicolet, M., Lohmann, U., Gallavardin, S., Saito, A., Nillius, B., Bingemer, H., Abbatt, J. P. D., Ardon, K., Levin, Z., Ganor, E., Georgakopoulos, D. G., Saunders, C., and Vali, G.: Resurgence in Ice Nuclei Measurement Research, submitted, B. Am. Meteorol. Soc., 2010.

Dymarska, M., Murray, B. J., Sun, L. M., Eastwood, M. L., Knopf, D. A., and Bertram, A. K.: Deposition ice nucleation on soot at temperatures relevant for the lower troposphere, J. Geophys. Res.-Atmos., 111(D4), doi:10.1029/2005JD006627, 2006.

Eastwood, M. L., Cremel, S., Gehrke, C., Girard, E., and Bertram, A. K.: Ice nucleation on mineral dust particles: Onset conditions, nucleation rates and contact angles, Journal of Geophysical Research-Atmospheres, 113, doi:10.1029/2008JD010639, 2008.

Eastwood, M. L., Cremel, S., Wheeler, M., Murray, B. J., Girard, E., and Bertram, A. K.: Effects of sulfuric acid and ammonium sulfate coatings on the ice nucleation properties of kaolinite particles, Geophys. Res. Lett., 36, L02811, doi:10.1029/2008GL035997, 2009.

Eidhammer, T., DeMott, P. J., Rogers, D. C., Prenni, A. J., Petters, M. D., Twohy, C. H., Rogers, D. C., Stith, J., Heymsfield, A., Wang, Z., Haimov, S., French, J., Pratt, K., Prather, K., Murphy, S., Seinfeld, J., Subramanian, R., and Kreidenweis, S. M.: Ice initiation by aerosol particles: Measured and predicted ice nuclei concentrations versus measured ice crystal concentrations in an orographic wave cloud, Journal of Atmospheric Sciences, 67, 2417-2436, doi:10.1175/2010JAS3266.1, 2010.

Field, P. R., Möhler, O., Connolly, P., Krämer, M., Cotton, R., Heymsfield, A. J., Saathoff, H., and Schnaiter, M.: Some ice nucleation characteristics of Asian and Saharan desert dust, Atmos. Chem. Phys., 6, 2991-3006, doi:10.5194/acp-6-2991-2006, 2006.

IPCC: Changes in Atmospheric Constituents and in Radiative Forcing, in: Climate Change 2007: The Physical Science Basis. Contribution of Working Group I to the Fourth Assessment Report of the Intergovernmental Panel on Climate Change, Cambridge and New York, Cambridge Univ. Press, 2007.

Kanji, Z. A. and Abbatt, J. P. D.: Laboratory studies of ice formation via deposition mode nucleation onto mineral dust and n-hexane soot samples, J. Geophys. Res.-Atmos., 111(D16),
D16204, doi:10.1029/2005JD006766, 2006.

Kanji, Z. A. and Abbatt, J. P. D.: Ice Nucleation onto Arizona Test Dust at Cirrus Temperatures: Effect of Temperature and Aerosol Size on Onset Relative Humidity, J. Phys. Chem. A, 114, 935941, 2009a.

Kanji, Z. A. and Abbatt, J. P. D.: The University of Toronto Continuous Flow Diffusion Chamber (UT-CFDC): A Simple Design for Ice Nucleation Studies, Aerosol. Sci. Tech., 43(7), 730-738, 2009b.

Kanji, Z. A., Florea, O., and Abbatt, J. P. D.: Ice formation via deposition nucleation on mineral dust and organics: dependence of onset relative humidity on total particulate surface area, Environ. Res. Lett., 3(2), 025004, doi:10.1088/1748-9326/3/2/025004, 2008.

Knopf, D. A. and Koop, T.: Heterogeneous nucleation of ice on surrogates of mineral dust, J. Geophys. Res.-Atmos., 111(D12), D12201, doi:10.1029/2005JD006894, 2006.

Koehler, K. A., Kreidenweis, S. M., DeMott, P. J., Petters, M. D., Prenni, A. J., and Möhler, O.: Investigations of the impact of natural dust aerosol on cold cloud formation, Atmos. Chem. Phys. Discuss., 10, 19343-19380, doi:10.5194/acpd-10-19343-2010, 2010.

Koop, T., Luo, B. P., Tsias, A., and Peter, T.: Water activity as the determinant for homogeneous ice nucleation in aqueous solutions, Nature, 406(6796), 611-614, 2000.

Laaksonen, A., Talanquer, V., and Oxtoby, D. W.: Nucleation Measurements, Theory, and Atmospheric Applications, Annu. Rev. Phys. Chem., 46, 489-524, 1995.

Marcolli, C., Gedamke, S., Peter, T., and Zobrist, B.: Efficiency of immersion mode ice nucleation on surrogates of mineral dust, Atmos. Chem. Phys., 7, 5081-5091, doi:10.5194/acp-7-50812007, 2007.

Möhler, O., Buttner, S., Linke, C., Schnaiter, M., Saathoff, H., Stetzer, O., Wagner, R., Kramer, M., Mangold, A., Ebert, V., and Schurath, U.: Effect of sulfuric acid coating on heterogeneous ice nucleation by soot aerosol particles, J. Geophys. Res.-Atmos., 110(D11), D11210, doi:10.1029/2004jd005169, 2005 a.

Möhler, O., Linke, C., Saathoff, H., Schnaiter, M., Wagner, R., Mangold, A., Kramer, M. and Schurath, U.: Ice nucleation on flame soot aerosol of different organic carbon content, Meteorol. Z., 14(4), 477-484, 2005b.

Möhler, O., Field, P. R., Connolly, P., Benz, S., Saathoff, H., Schnaiter, M., Wagner, R., Cotton, R., Krämer, M., Mangold, A., and Heymsfield, A. J.: Efficiency of the deposition mode ice nucleation on mineral dust particles, Atmos. Chem. Phys., 6, 3007-3021, doi:10.5194/acp-6-3007-2006, 2006.

Möhler, O., DeMott, P. J., Stetzer, O., and ICIS-2007 team: The Fourth International Ice Nucleation Workshop ICIS 2007, Proceedings of 15th ICCP, Cancun, Mexico, 7-11 July 2008.

Möhler, O., Georgakopoulos, D. G., Morris, C. E., Benz, S., Ebert, V., Hunsmann, S., Saathoff, H., Schnaiter, M., and Wagner, R.: Heterogeneous ice nucleation activity of bacteria: new laboratory experiments at simulated cloud conditions, Biogeosciences, 5, 1425-1435, doi:10.5194/bg-5-1425-2008, 2008.

Murphy, D. M. and Koop, T.: Review of the vapour pressures of ice and supercooled water for atmospheric applications, Q. J. Roy. Astron. Soc., 131(608), 1539-1565, 2005.

Salam, A., Lohmann, U., Crenna, B., Lesins, G., Klages, P., Rogers, D., Irani, R., MacGillivray, A., and Coffin, M.: Ice nucleation 
studies of mineral dust particles with a new continuous flow diffusion chamber, Aerosol Science and Technology, 40(2), 134143, 2006.

Salam, A., Lohmann, U., and Lesins, G.: Ice nucleation of ammonia gas exposed montmorillonite mineral dust particles, Atmos. Chem. Phys., 7, 3923-3931, doi:10.5194/acp-7-3923-2007, 2007.

Salam, A., Lesins, G., and Lohmann, U.: Laboratory study of heterogeneous ice nucleation in deposition mode of montmorillonite mineral dust particles aged with ammonia, sulfur dioxide, and ozone at polluted atmospheric concentrations, Air Quality Atmosphere \& Health, 1, 135-142, doi:10.1007/s11869-008-0019-6, 2008.

Stetzer, O., Baschek, B., Luond, F., and Lohmann, U.: The Zurich Ice Nucleation Chamber (ZINC) - A new instrument to investigate atmospheric ice formation, Aerosol Sci. Tech., 42(1), 64-74, 2008.

Szyrmer, W. and Zawadzki, I.: Biogenic and anthropogenic sources of ice-forming nuclei: A review, B. Am. Meteorol. Soc., 78(2), 209-228, 1997.

Twohy, C. H. and Poellot, M. R.: Chemical characteristics of ice residual nuclei in anvil cirrus clouds: evidence for homogeneous and heterogeneous ice formation, Atmos. Chem. Phys., 5, 22892297, doi:10.5194/acp-5-2289-2005, 2005.
Vali, G.: Ice Nucleation Workshop, 1975 Laramie, Wyoming, 19 May-6 June 1975, B. Am. Meteorol. Soc., 56(11), 1180-1184, 1975.

Vlasenko, A., Sjogren, S., Weingartnerm, E., Gaggeler, H. W., and Ammann, M.: Generation of submicron Arizona test dust aerosol: Chemical and hygroscopic properties, Aerosol Sci. Tech., 39(5), 452-460, 2005.

Wagner, R., Benz, S., Möhler, O., Saathoff, H., and Schurath, U.: Probing ice clouds by broadband mid-infrared extinction spectroscopy: case studies from ice nucleation experiments in the AIDA aerosol and cloud chamber, Atmos. Chem. Phys., 6, 47754800, doi:10.5194/acp-6-4775-2006, 2006.

Welti, A., Lüönd, F., Stetzer, O., and Lohmann, U.: Influence of particle size on the ice nucleating ability of mineral dusts, Atmos. Chem. Phys., 9, 6705-6715, doi:10.5194/acp-9-6705-2009, 2009.

Zobrist, B., Marcolli, C., Koop, T., Luo, B. P., Murphy, D. M., Lohmann, U., Zardini, A. A., Krieger, U. K., Corti, T., Cziczo, D. J., Fueglistaler, S., Hudson, P. K., Thomson, D. S., and Peter, T.: Oxalic acid as a heterogeneous ice nucleus in the upper troposphere and its indirect aerosol effect, Atmos. Chem. Phys., 6, 3115-3129, doi:10.5194/acp-6-3115-2006, 2006. 